\title{
MODELING OF TREE GROWTH AFTER FOREST FIRE IN MOUNT CIREMAI NATIONAL PARK, INDONESIA
}

\author{
ANDES HAMURABY ROZAK ${ }^{1 *}$ and TEDI SETIADI ${ }^{2}$ \\ 'Cibodas Botanic Gardens, Indonesian Institute of Sciences, Cianjur 43253, Indonesia \\ ${ }^{2}$ Bird Conservation Society, Bandung 40184, Indonesia
}

Received 12 July 2013/Accepted: 14 October 2016

\begin{abstract}
Forest fire is a massive threat towards tropical forest causing various negative impacts to nature and human being. Forest fire often leads to alteration of forest structure and its functions. This study of tree growth after forest fire was conducted using a model simulation. The model was performed at the individual level of plant community and built to analyze the potential of tree growth and its scenario for post-fire recovery. Five important tree species from montane forest of Mount Ciremai were chosen to build the model based on four main parameters i.e. plant growth rate, diameter at breast height (DBH), tree-to-grass competition and tree-to-tree competition. The scenario of postfire recovery was performed by replanting similar species with $5 \mathrm{~cm}$ DBH seedling. Prediction from our model showed that most of the chosen species would recover to its pre-fire condition after $37-50$ years. Considering the limitation of competition after re-planting, it was suggested to minimize tree to tree competition and applied silvicultural treatments to maximize tree growth and tree community recovery.
\end{abstract}

Keywords: Forest fire, Mount Ciremai National Park, tree growth model, tropical montane forest

\section{INTRODUCTION}

Nowadays, forest fire is a serious threat towards tropical land including tropical forest, plantation and other forestry land. Fire used to be extremely rare in tropical forests, leaving ample time for forests to regenerate to pre-fire conditions. Moreover, undisturbed old-grown forests were difficult to burn due to their air humidity and high moisture content in soil and litter, even after prolonged droughts (Slik et al. 2010; Knox \& Clarke 2012). However, nowadays, tropical forest fires occur more frequently and at larger spatial scales than in the previous decades (van Nieustadt \& Sheil 2005; Laurance 2007; Slik et al. 2008). In recent years, forest fire occurs every year in dry season and had become the characteristic of disturbed tropical forest ecosystem (Stolle et al.2003).

Several reasons can be identified as main causes of catastrophic fire i.e. population growth, changes in land-use practices and short-term climatic oscillations commonly known as ElNino

\footnotetext{
* Corresponding author: andes.hamuraby.rozak@lipi.go.id
}

(Kinnaird \& O'Brien 1998; Le Page et al. 2008). Forest fire causes several negative impacts to nature and human being. It affects public health as the net forest emissions may have released carbon which equivalent to $41 \%$ of worldwide fossil fuel used in 1997- 1998 (Cochrane 2003). The fire itself led to local extinctions of some plants and animals. Furthermore, a country may suffer economic losses in forestry, non-timber forest products and agriculture. Fire is able to deteriorate forest structure, tree species diversity, tree species composition, aboveground biomass and forest soil (Flannigan et al. 2000; McIntosh et al. 2005; Knox \& Clarke 2012).

Several studies related to forest fire and its recovery had been conducted in tropical forest of Indonesia. Slik et al. (2002) recorded that tree density (diameter $>10 \mathrm{~cm}$ ) and canopy closure in Borneo were able to recover within 10 to 15 years. Other studies had also been conducted focusing on recovery of the habitat and species diversity after forest fire in Borneo (Slik 2004; Watanabe et al. 2009; Slik et al. 2010). However, tree ingrowths during this initial phase of regeneration consist mostly of early successional, fast-growing tree 
species with low wood densities. Successful recovery of forest aboveground biomass, therefore, depends strongly on the regeneration of the pre-fire species composition (Slik et al. 2008). In addition, tree community recovery after forest fire was also determined by several conditions i.e. growth rate, resprouting rate, competition and survival rate.

Study on post-fire recovery using ecological modeling as a prediction tool has never been applied in Indonesian forest, specifically in tropical montane forest. In this study, we have modeled the recovery of five dominant trees in Mount Ciremai National Park (MCNP) after forest fire. The model was developed using the growth model of Menaut et al. (1990). However, tree biomass calculation was modified by replacing the estimation of volume from diameter and height function (Botkin's equation; Botkin et al. 1972) to allometric equation of biomass calculation (Basuki et al. 2009). The biomass equation was applied due to the importance of biomass re-growth rate in post-fire forest recovery (Minchella et al.2009).

The potential growth of the selected trees was predicted for fifty-year projection. The selection of tree species was based on plant community data in MCNP by Rozak (2007). Recent publication showed that MCNP experienced at least four forest fire events in 2011, especially in long dry season (Syachera 2011). Therefore, this study was aimed to: predict the potential growth of selected trees before forest fire event (normal growth) and predict the best scenario for replantation based on tree to tree competition. The results of the study were expected to provide information related to post-fire forest recovery which is important for MCNP management.

\section{MATERIALS AND METHODS}

\section{Study Site and Tree Community Data}

Mount Ciremai National Park (MCNP) is located in West Java Province ca. $270 \mathrm{~km}$ eastward from Jakarta, the capital of Indonesia. Geographically, the MCNP is situated at $108^{\circ} 20^{\prime}-$ $108^{\circ} 40^{\prime} \mathrm{E}$ and $6^{\circ} 40^{\prime}-6^{\circ} 58^{\prime} \mathrm{S}$. The highest elevation reaches $3,078 \mathrm{~m}$ asl. making this mountain to be the highest mountain in West Java. Topographically, around $26.52 \%$ of the area has $0^{\circ}-8^{\circ}$ slope. The rest of the area has slope more than $8^{\circ}$ or equal to $73.48 \%$ of the area (Rozak \& Gunawan 2015). The annual mean of precipitation is $2,000 \mathrm{~mm}$ and the annual temperature is $22{ }^{\circ} \mathrm{C}$ (Kuningan Government 2011). The tree community data were collected in 2007 from Cigugur-Darma Resort located at the eastern part of the MCNP. Tree community data were collected from twenty quadrat plots $(10 \times 10$ $\mathrm{m})$ which were placed in parallel to mountain topography. Within each plot, all live trees taller than $1.3 \mathrm{~m}$ were identified and $\mathrm{DBH}$ greater than $10 \mathrm{~cm}$ were measured.

Five tree species with the highest Important Value Index (IVI) were chosen for model development and the name of those tree species were standardized through The Plant List website (www.theplantlist.org). The Important Value Index were generated from three parameters i.e. dominance index, abundance index and frequency index. We selected the DBH from Engelhardtia spicata Blume, Ficus ribes Reinw. ex Blume, Trema orientalis (L) Blume, Saurauriapendula Blume and Lithocarpus pallidus (Blume) Rehder in the study site, as the reference size of initial DBH before forest fire event (Table 1).

Table 1 The Important Value Index (IVI) of five dominated tree species in Mount Ciremai National Park (MCNP)

\begin{tabular}{lccccc}
\hline \multicolumn{1}{c}{ Species } & IVI & DBH & H & $D_{\max }$ & $\mathrm{H}_{\max }$ \\
\hline Engelhardtia spicata Lechen ex Blume & 32,482 & 35 & 22 & 60 & 25 \\
Ficus ribes Reinw. ex Blume & 28,469 & 15 & 8 & 30 & 15 \\
Trema orientalis (L.) Blume & 21,582 & 34 & 16 & 60 & 25 \\
Saurania pendula Blume & 19,891 & 17 & 7 & 30 & 17 \\
Lithocarpus pallidus (Blume) Rehder & 18,041 & 12 & 9 & 35 & 21 \\
\hline
\end{tabular}

Notes: IVI = Important Value Index; DBH = Diameter at Breast Height $(\mathrm{cm}) ; \mathrm{H}=$ actual height of tree (m) measured by hagameter; $\mathrm{D}_{\max }=$ maximum diameter $(\mathrm{cm}) ; \mathrm{H}_{\max }=$ maximum height $(\mathrm{m})$. Value of $\mathrm{D}_{\max }$ and $\mathrm{H}_{\max }$ were derived from Hanum and van der Maesen (1997) as well as van der Vossen and Wessel (2000) 


\section{Modeling Process}

A model to explore the growth trend of tree structure which suffered from forest fire in the tropical mountain forest was developed. The model follows a Gleasonian approach, integrating the biology and the fate of all individuals throughout their life cycle (Menaut et al. 1990). The model was based on two conditions of selected tree growth and estimated size of each tree. These conditions were:

1. normal growth which means that there was no forest fire. In this condition, the biomass of the tree at initial condition (year 0 ), at the next 25 years and at the next 50 years were counted;

2. plant growth after plantation which means that there was forest fire occurred; the selected trees were planted accordingly. Therefore, the model was based on the growth and estimated biomass of the replanted trees.

The time of each tree species reaching the same tree size at normal condition (without fire) was recorded. The modeling was focused on the components of replanted tree competition with its potential competitors i.e. grass (especially for the early stage of the growth) and other tree species. The model of tree growth was developed in "R software". The inputs of the model were:

1. An initial tree community structure from field data survey;

2. Allometric equation consisted of diameter, height and biomass;

3. Plant growth rate;

4. Parameter of competition, both tree to grass and tree to tree competitions.

\section{Modeling the normal tree growth}

The used approach in this study was developed by Menaut et al. (1990) who expressed potential tree growth as a function of growth rate (G) multiplied by volume $\left(\mathrm{V}, \mathrm{m}^{3}\right)$ of tree:

$$
\frac{\mathrm{dV}}{\mathrm{dt}}=\mathrm{G} * \mathrm{~V}
$$

Menaut et al. (1990) adopted volume equation from Botkin et al. (1972) which is:

$$
\mathrm{V}=\mathrm{D}^{2} * \frac{1-\mathrm{D} * \mathrm{H}}{\mathrm{D}_{\max } * \mathrm{H}_{\max }}
$$

where:

$\mathrm{D}=$ diameter at breast height in $\mathrm{cm}$;

$\mathrm{D}_{\text {max }}=$ maximum diameter at breast height in $\mathrm{cm}$;

$\mathrm{H}=$ heightin $\mathrm{m}$;

$\mathrm{H}_{\max }=$ maximum height in $\mathrm{m}$.
Parameters D and $\mathrm{H}$ were collected from field data. Parameters $\mathrm{D}_{\text {max }}$ and $\mathrm{H}_{\max }$ were according to Hanum and van der Maesen (1997) as well as van der Vossen and Wessel (2000).

The results obtained based on equation 2 were negative and therefore, unrealistic. Subsequently, the original equation from Botkin et al. (1972) was applied as in Equation 3.

$$
\mathrm{V}=\mathrm{D}^{2} *\left(1-\frac{\mathrm{D} * \mathrm{H}}{\mathrm{D}_{\max } * \mathrm{H}_{\max }}\right)
$$

Combining equations (1) and (3) to become equation (4):

$$
\frac{\mathrm{dV}}{\mathrm{dt}}=\mathrm{G} * \mathrm{D}^{2} *\left(1-\frac{\mathrm{D} * \mathrm{H}}{\mathrm{D}_{\max } * \mathrm{H}_{\max }}\right) \ldots \ldots \ldots \ldots \ldots \ldots
$$

The following equation was developed using equation (1) and (3) to combine normal growth rate of tree community and to take into account the tree-to-tree competition $\left(\mathrm{C}_{\mathrm{t}}\right)$ :

$\mathrm{V}[\mathrm{t}+1]=\mathrm{V}[\mathrm{t}]+\mathrm{G} * \mathrm{D}^{2} *\left(1-\frac{\mathrm{D} * \mathrm{H}}{\mathrm{D}_{\max } * \mathrm{H}_{\max }}\right) * \mathrm{C}_{\mathrm{tt}} \ldots \ldots$ (5)

Basuki et al. (2009) had developed more accurate equations to predict tree biomass (B, $\mathrm{kg} /$ tree) using allometric model (with $\mathrm{r}^{2}=$ 0.963) of the tree species found in mixed tropical forest based on diameter at breast height (DBH). The equation is expressed by:

$$
\ln (\mathrm{B})=\mathrm{c}+\alpha * \ln (\mathrm{DBH})
$$

which means:

$$
\mathrm{B}=\mathrm{e}^{\mathrm{c}} *(\mathrm{DBH})^{\alpha}
$$

where:

$\mathrm{c}=$ the intercept $(=-1.201)$

$\alpha=$ the slope coefficient $(=2.196)$ of Basuki et al. (2009) equations.

Plant growth is considered as the changing of biomass over time (replacing the volume equation (5) to biomass equation (7)). Therefore, formula to measure the next year biomass is:

$\mathrm{B}[\mathrm{t}+1]=\mathrm{B}[\mathrm{t}]+\mathrm{G} * \mathrm{e}^{-1.201} *(\mathrm{DBH})^{2.196} * \mathrm{C}_{\mathrm{tt}} \ldots \ldots \ldots . . \quad$ (8)

\section{Modeling tree growth after replantation}

Forest fire caused all tree community perished in the study area and the replanting was done using selected tree species which is important for the area. The importance of these tree species was represented by the high important value indices shown for these tree species. 
After forest fire, in the succession process of the community, there were interactions and competitions from the pioneer species, such as competition within pioneer species to get light, nutrition, etc. According to Menaut et al. (1990), the competition component encompassed two kinds of competitive interactions i.e. tree-tograss competition $\left(\mathrm{C}_{\mathrm{tg}}\right)$ and tree-to-tree competition $\left(\mathrm{C}_{\mathrm{tt}}\right)$. Based on Menaut et al. (1990), the $\mathrm{C}_{\mathrm{tg}}$ value used was 0.99 for a tree reaching $2 \mathrm{~m}$ high and $\mathrm{C}_{\mathrm{tt}}$ value used were $0.3,0.5$ and 0.7 .

The change of biomass from one year to the next year based on its potential growth (equations $7 \& 8)$ limited by competitions $\left(\mathrm{C}_{\mathrm{tt}}\right.$ and $\left.\mathrm{C}_{\mathrm{tg}}\right)$ would be:

Bnew $[\mathrm{t}+1]=$ Bnew $[\mathrm{t}]+\mathrm{G} * \mathrm{e}^{-1.201} *(\mathrm{DBH})^{2.196} * \mathrm{C}_{\mathrm{tg}} * \mathrm{C}_{\mathrm{tt}} \cdots(9)$

\section{Data Interpretation}

The projection of tree community in Mount Ciremai National Park (MCNP) for 50 years was examined. Tree growth was modeled to get the pre-fire condition, represented by the value of total aboveground biomass between the normal growth projection (equation 8) and after replantation (equation 9). One important parameter to determine the speed of tree species growth is the value of tree to tree competition. The results of low, medium and high $\mathrm{C}_{\mathrm{tt}}$ were compared, i.e. $\mathrm{C}_{\mathrm{tt}}=0.3$ (three other tree canopies overlapped with replanted tree canopies), $\mathrm{C}_{\mathrm{tt}}=0.5$ (two other tree canopies overlapped with replanted tree canopies) and $\mathrm{C}_{\mathrm{tt}}=0.7$ (only one tree canopy overlapped with replanted tree canopies). Overlapped tree canopies were used to characterize the tree-to-tree competition. Other important coefficient is $\mathrm{C}_{\mathrm{tg}}$ which reflected the intensity of competition from grass (and other herbaceous layer) towards the newly planted trees.

\section{RESULTS AND DISCUSSION}

Plant growth model provided the projection of future size of the plant. In this study, the model was developed based on several parameters i.e. plant growth rate, competition and initial biometric of the measured tree. Furthermore, the model tried to predict the future state of tree community after being suffered from forest fire and had been replanted. The replantation was an effort to accelerate the succession of the tree community in order to shorten the recovery period. Previous publications mentioned that tropical forest regeneration to pre-fire condition took a long time (Viedma et al. 1997; Kinnaird \& O'Brien 1998).

Four of five replanted species reached the prefire condition within 37 - 50 years (Fig. 1 to 5). Based on the comparison among three after-fire models and pre-fire model, the fastest model to reach the pre-fire condition/initial biomass (Table 2) was the model with lower value of treeto-tree competition $\left(\mathrm{C}_{\mathrm{tt}}\right)$. The value of $\mathrm{C}_{\mathrm{tt}}$ was generated from the total number of possible overlapped canopies among neighboring trees (Menaut et al.1990). In general, model having one overlapped tree canopy provided the fastest period to reach the pre-fire condition. Exceptionally, $S$. pendula did not reach the expected value within the 50 years period.

Table 2 Biomass projection from five tree species without fire event in Mount Ciremai National Park (MCNP)

\begin{tabular}{lcccc}
\hline \multicolumn{1}{c}{ Species } & DBH & Initial Biomass (kg) & Biomass-25 (kg) & Biomass-50 (kg) \\
\hline Engelhardtia spicata & 35 & 742 & 1,060 & 1,538 \\
Ficus ribes & 15 & 115 & 186 & 304 \\
Trema orientalis & 34 & 696 & 949 & 1,311 \\
Saurania pendula & 17 & 152 & 222 & 331 \\
Lithocarpus pallidus & 12 & 115 & 296 & 788 \\
\hline
\end{tabular}

Notes: Biomass $-25=$ expected biomass after 25 years

Biomass $-50=$ expected biomass after 50 years 


\section{Biomass Growth after Replantation for Each} Tree

Engelhardtia spicata Lechen ex Blume

Biomass growth model for single tree species E. spicata (Fig. 1) predicted that in the next 50 years the tree would reach $1,315 \mathrm{~kg}$ ( with $\mathrm{C}_{\mathrm{tt}}=0.7$ ), $345 \mathrm{~kg}$ (with $\mathrm{C}_{\mathrm{tt}}=0.5$ ) and $87 \mathrm{~kg}$ (with $\mathrm{C}_{\mathrm{tt}}=0.3$ ). The model also predicted that E. spicata would reach the same biomass as initial/pre-fire biomass after 44 years of planting when based on $C_{t t}=0.7$. However, for $C_{t t}=0.5$ and $C_{t t}=0.3$, the model predicted that the biomass would not reach the initial/pre-fire biomass after 50 years of planting.
Ficus ribes Reinw. ex Blume

Based on the normal growth model, total biomass for F. ribes would be $304 \mathrm{~kg}$ in 50 years. Meanwhile, the initial/pre-fire total biomass based on this model was $115 \mathrm{~kg}$ (Table 2). Based on the results generated from the application of three different values of tree-to-tree competition on the model for plant recovery, it was predicted that the initial/pre-fire biomass would be achieved by $\mathrm{C}_{\mathrm{tt}}=0.7$ in 37 years after replantation. This prediction was the fastest period compared to the $C_{t t}=0.5$ and $C_{t t}=0.3$, which provided prediction of above 50 years after planting to reach the initial/pre-fire biomass (Fig. 2).

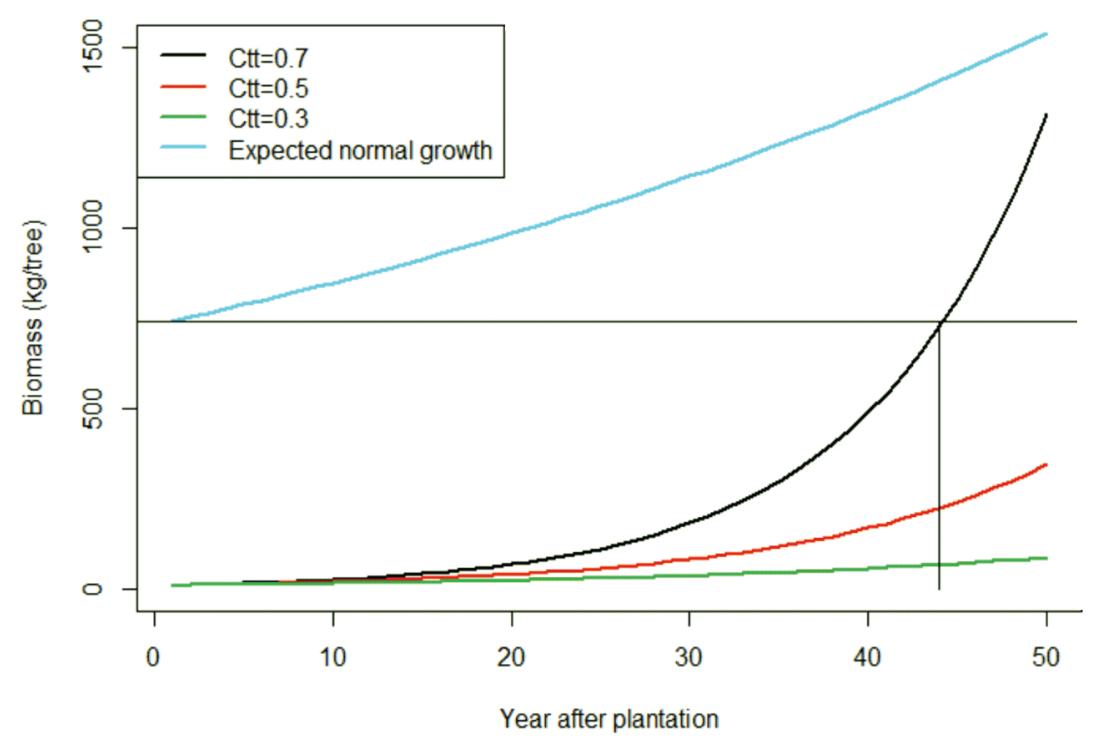

Figure 1 Biomass growth projection for Engelhardtia spicata

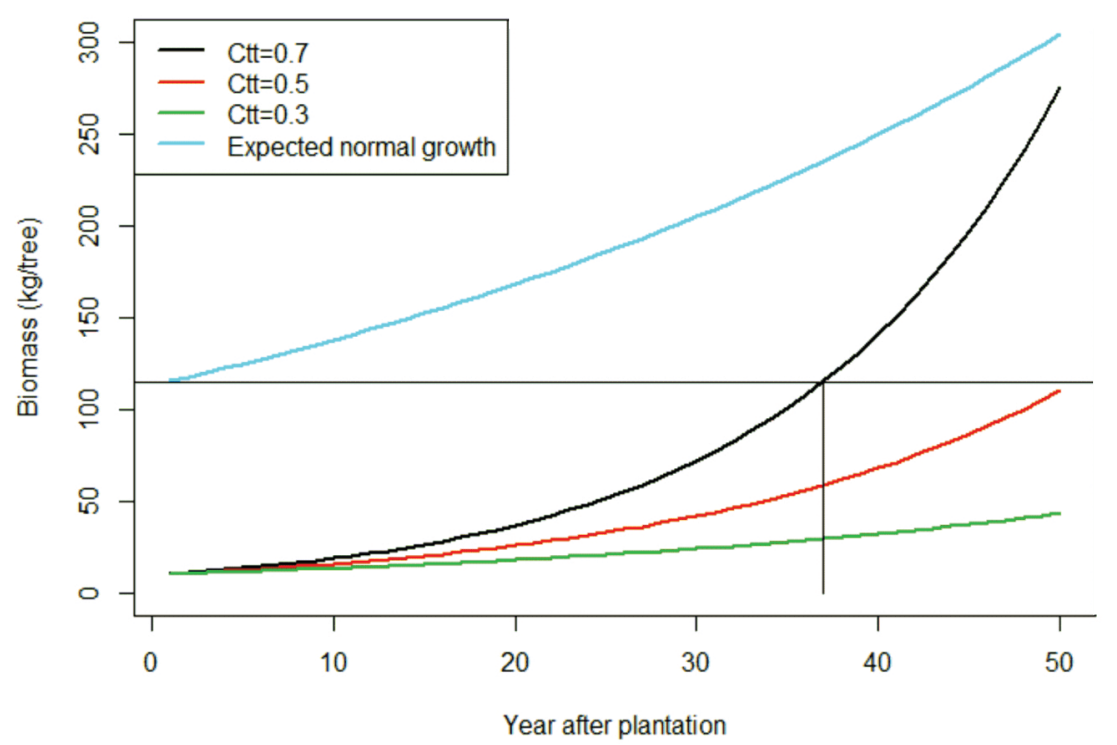

Figure 2 Biomass growth projection for Ficus ribes 
Trema orientalis (L.) Blume

Based on the normal growth model, the initial/pre-fire biomass for T. orientalis was $696 \mathrm{~kg}$. In 50 years projection, the total biomass would reach $1,311 \mathrm{~kg}$ (Table 2 ). Subsequently, $\mathrm{C}_{\mathrm{tt}}=0.7$ was predicted to reach the initial/pre-fire condition within 50 years after planting (Fig. 3). Meanwhile, the $\mathrm{C}_{\mathrm{tt}}=0.5$ and $\mathrm{C}_{\mathrm{tt}}=0.3$ were predicted to provide lower biomass at all projection periods.

\section{Sauraviapendula Blume}

The initial biomass of $S$. pendula predicted by the normal growth model was $152 \mathrm{~kg}$. Within
50 years after planting, the total biomass of $S$. pendula was predicted to reach $331 \mathrm{~kg}$ (Table 2). However, the given value within 50 years period from the post-fire model did not reach the initial biomass value obtained from the normal growth model. Moreover, all results of the post-fire model considering three different values of treeto-tree competition were lower than the results from the normal growth model. For instance, in the next 50 years, tree biomass would be $145 \mathrm{~kg}$ (for $\mathrm{C}_{\mathrm{tt}}=0.7$ ), $69 \mathrm{~kg}\left(\right.$ for $\mathrm{C}_{\mathrm{tt}}=0.5$ ) and $33 \mathrm{~kg}$ (for $\left.\mathrm{C}_{\mathrm{tt}}=0.3\right)$ (Fig. 4).

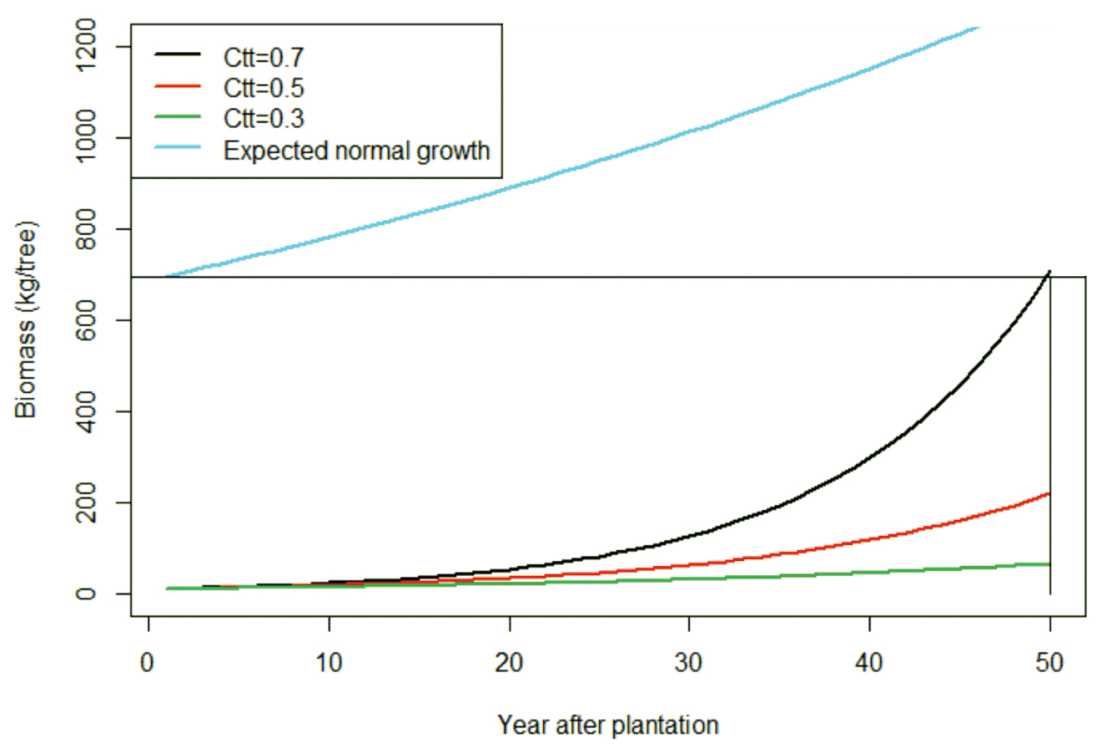

Figure 3 Biomass growth projection for Trema orientalis

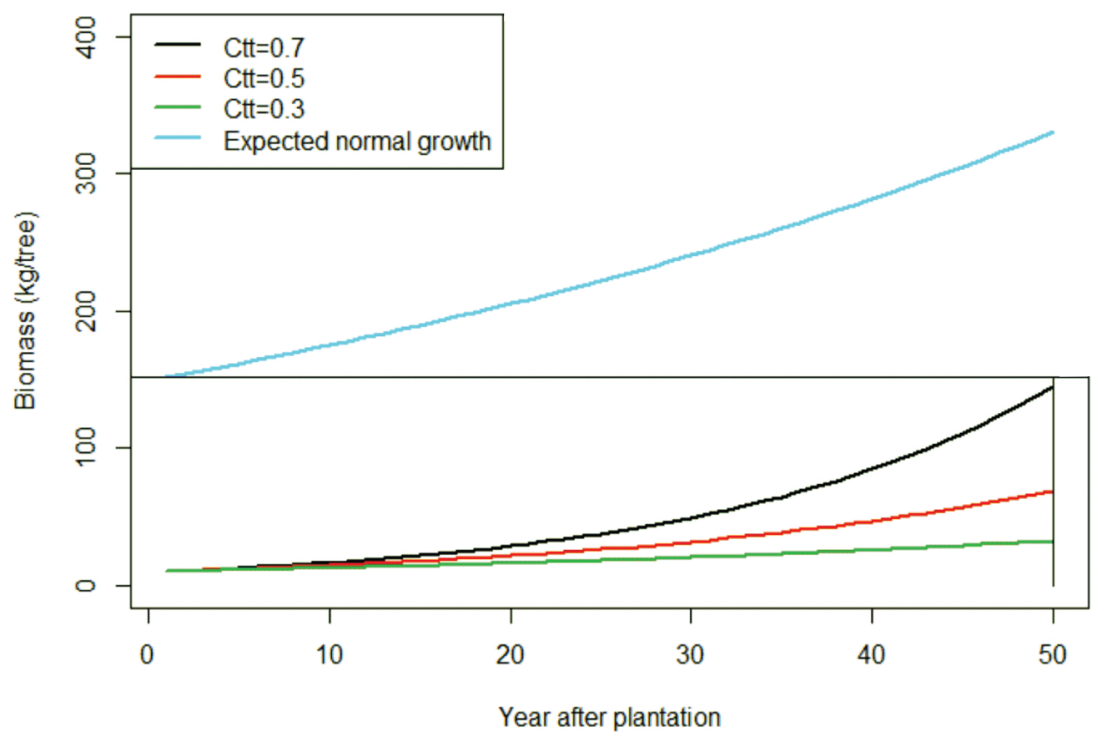

Figure 4 Biomass growth projection for Sauravia pendula 


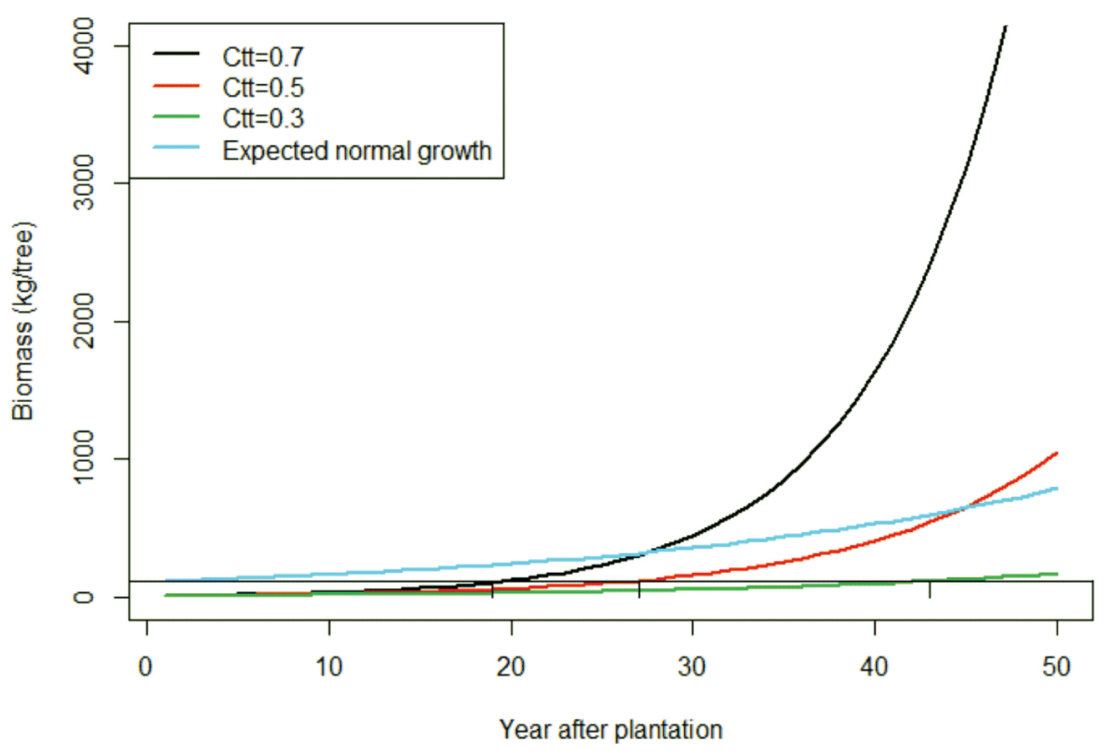

Figure 5 Biomass growth projection for Lithocarpus pallidus

\section{Lithocarpuspallidus (Blume) Rehder}

According to the pre-fire model, the initial biomass of L. pallidus was $115 \mathrm{~kg}$ and total biomass for 50 years after planting was predicted to be $788 \mathrm{~kg}$ (Table 2). Interesting results were shown on L. pallidus which had three possible values of tree-to-tree competition within 50 years after replanting. For $\mathrm{C}_{\mathrm{tt}}=0.7$, the total initial/prefire biomass was predicted to be reached in 19 years after replanting. For $C_{t t}=0.5$, the total initial/pre-fire biomass was predicted to be reached in 27 years after replanting, while $C_{t t}=0.3$ was predicted to reach the total initial/pre-fire biomass in 43 years after replanting (Fig. 5). Consequently, the number of neighboring trees can be different to get expected plant growth within certain period. For instance, L. pallidus can grow with its canopy overlapped with the canopies of two other trees.

\section{Factor Controlling Tree Growth}

Other contributing factor to overall results was the initial biometric of tree species i.e. Diameter at Breast Height $(\mathrm{DBH})$ and growth rate. The application of intensive silvicultural treatments is required to increase tree growth rate (Peña-Carlos et al. 2008). Among applicable silvicultural treatments to increase tree growth rate are: 1 . reducing the amount of vegetations competing with tree seedlings (minimizing $\mathrm{C}_{\mathrm{tt}}$ and $\mathrm{C}_{\mathrm{tg}}$ ); 2 . early-fertilizing; 3. thinning; and 4. pruning
(Gonzales-Ochoa \& de las Heras 2002; GonzalesOchoa et al. 2004; Zald et al. 2008).

\section{Model Improvement Consideration}

Based on the results obtained from the developed models, it is important to redevelop the model because at some point (for example $\mathrm{C}_{\mathrm{tt}}$ $=0.7$, Lithocarpus pallidus, between year $30-50$, Fig. 5) the biomass growth seemed to be unrealistic compared to the expected normal growth. The possibility is to develop allometric equation using logistic model. The tree-to-tree competition value should also be remeasured to include site specific factor, because the Menaut's data only included the savannah ecosystem.

\section{CONCLUSIONS}

The models developed in this study predicted normal and after-replantated tree growth. In general, this study provided further information regarding tree growth after replantation in tropical montane forests.

\section{ACKNOWLEDGEMENTS}

We are grateful to the Cibodas Botanic Gardens (Indonesian Institute of Sciences) and Mount Ciremai National Park (Ministry of 
Forestry, Republic of Indonesia) for funding and granting permission to conduct research in the Mount Ciremai National Park. We thank Dr William Cheung for constructive suggestions on our work and Ayu S. Nurinsiyah for improving the text.

\section{REFERENCES}

Basuki TM, van Laake PE, Skidmore AK, Hussin YA. 2009. Allometric equations for estimating the aboveground biomass in tropical lowland Dipterocarp forests. For Ecol Manage 257:1684-94.

Botkin DB, Janak JF, Walis JR. 1972. Some ecological consequences of a computer model of forest growth. J Ecol 60(3):649-872.

Cochrane MA. 2003. Fire science for rainforests. Nature 421:913-9.

Flannigan MD, Stocks BJ, Wotton BM. 2000. Climate change and forest fires. Sci Total Environ 262:221-9.

Gonzales-Ochoa A, de las Heras J. 2002. Effects of post-fire silviculture practices on Pachyrbinus squamosus defoliation levels and growth of Pinus halepenses Mill. For Ecol Manage 167:185-94.

Gonzales-Ochoa A, Lopez-Serrano FR, de las Heras J. 2004. Does post-fire forest management increase tree growth and cone production in Pinus halepensis? For Ecol Manage 188:235-47.

Hanum IF, van der Maesen LJG, editors. 1997. Plant resources of South-East Asia No. 11: auxiliary plants. Leiden (NL): Backhuys Publisher. p.252-5.

Kinnaird MF, O'Brien TG. 1998. Ecological effects of wildfire on lowland rainforest in Sumatra. Conserv Biol 12(5):954-6.

Knox KJE, Clarke PJ. 2012. Fire severity, feedback effects and resilience to alternative community states in forest assemblages. For Ecol Manage 265:47-54.

Kuningan Government. 2011. Mount Ciremai National Park. Available online on www.kuningankab.go.id. Accessed on $14^{\text {th }}$ February 2011. (In Indonesian).

Laurance WF. 2007. Forest destruction in tropical Asia. Curr Sci 93(11):1544-50.

Le Page Y, Pereira JMC, Trigo R, da Camara C, Oom D, Mota B. 2008. Global fire activity patterns (19962006) and climatic influence: an analysis using the World Fire Atlas. Atmos Chem Phys 8:1911-24.

McIntosh PD, Laffan MD, Hewitt AE. 2005. The role of fire and nutrient loss in the genesis of the forest soils of Tasmania and southern New Zealand. For Ecol Manage 220:185-215.

Menaut JC, Gignoux J, Prado C, Clobert J. 1990. Tree community dynamics in a humid savanna of the
Cote-d'Ivoire: modeling the effects of fire and competition with grass and neighbours. J Biogeogr 17:471-81.

Minchella A, Del Fratte F, Capogna F, Anselmi S, Manes F. 2009. Use of multitemporal SAR data for monitoring vegetation recovery of Mediterranean burned areas. Remote Sens Environ 113:588-97.

Peña-Carlos M, Peters EM, Justiniano MJ, Bongers F, Blate GM, Fredericksen TS, Putz FE. 2008. Regeneration of commercial tree species following silvicultural treatments in a moist tropical forest. For Ecol Manage 255:1283-93.

Rozak AH. 2007. Medicinal plants and vegetation analysis in Mount Ciremai National Park, West Java, Indonesia. In Siregar M. et al., editor. Proceeding of the Usada Bali plant conservation and its support to ecotourism, "Eka Karya" Botanic Gardens, Indonesian Institute of Sciences, Bali (ID). p.18795. (In Indonesian).

Rozak AH, Gunawan H. 2015. Altitudinal gradient affects on trees and stand attributes in Mount Ciremai National Park, West Java, Indonesia. Jurnal Penelitian Kehutanan Wallacea 4(2):93-9.

Slik JWF. 2004. El Niño droughts and their effects on tree species composition and diversity in tropical rain forests. Oecologia 141:114-20.

Slik JWF, Verburg RW, Kessler PJA. 2002. Effects of fire and selective logging on the tree species composition of lowland dipterocarp forest in East Kalimantan, Indonesia. Biodivers Conserv 11:85-98.

Slik JWF, Bernard CS, van Beek M, Breman FC, Eichhorn KAO. 2008. Tree diversity, composition, forest structure and aboveground biomass dynamics after single and repeated fire in a Bornean rain forest. Oecologia 158:579-88.

Slik JWF, Breman FC, Bernard C, van Beek M, Cannon CH, Eichhorn KAO, Sidiyasa K. 2010. Fire as a selective force in tropical forests: Species specific habitat preference and functional traits influence tree abundance after fire. Oecologia 164:841-9.

Stolle F, Chomitz KM, Lambin EF, Tomich TP. 2003. Land use and vegetation fires in Jambi Province, Sumatra, Indonesia. For Ecol Manage 179:277-92.

Syachera N. 2011. Kawasan TNGC terbakar [Mount Ciremai National Park was burned]. Available online on http://www.btngciremai.blogspot.co.id/ 2011_09_01_archive.html

The Plant List. 2013. The plant list. Version 1.1. Published on the Internet; http://www.theplantlist.org/ (accessed $1^{\text {st }}$ January 2013).

van der Vossen HAM, Wessel M, editors. 2000. Plant resources of South-East Asia No. 16: Stimulants. Leiden (NL): Backhuys Publisher. p.128-9. 
van Nieustadt MGL, Sheil D. 2005. Drought, fire and tree survival in a Borneo rain forest, East Kalimantan, Indonesia. J Ecol 93:191-201.

Viedma O, Melia J, Segarra D, Garcia-Haro J. 1997. Modeling rates of ecosystem recovery after fires by using Landsat TM data. Remote Sens Environ 61:383-98.
Watanabe NM, Suzuki E, Simbolon H. 2009. Reestablishment of rattans after forest fire in East Kalimantan, Borneo. Tropics 18(1):13-21.

Zald HSJ, Gray AN, North M, Kern RA. 2008. Initial tree regeneration responses to fire and thinning treatments in a Sierra Nevada mixed-conifer forest, USA. For Ecol Manage 256:168-79. 